\title{
Detection Contaminant DNA of a Pig on a Sample Meat Mills in Some City Markets Bengkulu, Using a Genetic Marker DNA Mitochondria Cytochrome B
}

\author{
Choirul Muslim ${ }^{1}$ Iin Isnaini ${ }^{2}$ Sipriyadi ${ }^{1, *}$
}

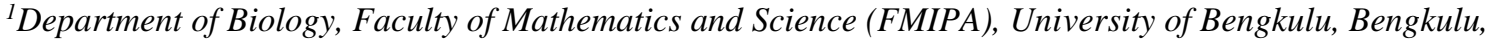 \\ Indonesia \\ ${ }^{2}$ Undergraduate Student, Department of Biology, Faculty of Mathematics and Science (FMIPA), University of \\ Bengkulu, Bengkulu, Indonesia \\ * Corresponding author. Email: sipriyadi@unib.ac.id
}

\begin{abstract}
The purpose of the study was to find out if there was a mixture of pork in ground beef samples in some Bengkulu city markets using the molecular Genetic DNA mitochondrial cytochrome b. The research was conducted from December 2019 to May 2020. Sampling was conducted at 10 meat mills in Bengkulu City (Pasar Panorama, Pasar Minggu, Pasar Barukoto, and Sungai Serut Fish Market). DNA isolation, DNA amplification, and electrophoresis are carried out in the biotechnology laboratory, Department of Biology, University of Bengkulu. The meat samples that had been milled were then performed genome DNA isolation following the Qiagen DNeasy for Food Kit protocol. PCR (Polymerous Chain Reaction) is carried out as many as 30 cycles with Primer Forward referring to and primary Reverse Mix (pork, cow, and chicken), Reverse Pork for pigs and Reverse cow for cows. PCR products are electrophobic on 1\% agarose gel and then visualized under UV light using Gel Document System Axygen. As a result of the study, on the primary use of Rcow all samples contained cow DNA. In primary use reverse pork, no DNA tape is amplified. In the primary use of Reverse mix from ten samples all containing cow DNA, one sample is thought to contain pig DNA i.e. s7 samples, and six of them contain chicken DNA (S1, S4, S5, S6, S7, and S8). Generally, meat milling in Bengkulu city located in Pasar Panorama, Pasar Minggu, Pasar Barukoto, and Sungai Serut Fish Market is not tainted with pork even though one sample is found, this is because it is influenced by the amount of meat that is milled still too much.
\end{abstract}

Keywords: Cytochrome b, meet milling, Pork Contamination

\section{INTRODUCTION}

Indonesian Constitution No. 7 of 1996 on Food states that food is a basic human need whose fulfillment is the basic right of every Indonesian. In this Constitution explained that food is safe, of good quality, nutritious, diverse, and sufficiently available is the main prerequisite that must be fulfilled in the effort to implement a food system [1]. Nutrition is a substance or chemical bond that is needed by the body to carry out its functions such as producing energy, growth, and maintenance of body tissues and regulating normal body functions (regulatory substances). Nutrition is divided into six groups, namely carbohydrates, fats, proteins, vitamins, minerals, and water. Protein itself is one of the nutrients that is composed of the elements carbon, hydrogen, oxygen, and nitrogen, besides that there is also sulfur and phosphorus. Protein has a function for tissue growth and maintenance, maintaining body neutrality, forming antibodies, regulating water balance, transporting nutrients, and as a source of energy [2].

Beef is a source of animal protein that is now widely traded both in modern and traditional markets. The need for beef continues to increase in line with the increasing population and public awareness of the importance of animal protein. Many processed foods are made from beef, such as meatballs, burgers, kebabs, etc. Business actors who do not yet have a meat mill will use meat grinding services in markets or places that provide meat grinding services. Meat milling is a means used by consumers or society in general to grind meat. Most of the consumers who use this service are those who usually own small 
businesses and use meat as a basic ingredient [3]. There are not too many meat mills in Bengkulu City, but this mills itself does not have clear rules regarding halal certification for meat mills. It is of concern that the meat grinding services in the market will accept consumers grinding non-halal meat.

Pigs are one of the animals that are forbidden according to Islamic law and have also been listed in the Indonesian Constitution No. 33 of 2014, pork is indeed haram for consumption by a Muslim [4]. The pig population in Bengkulu Province is still very high, this is due to the large area of forest habitat and agricultural land for the population and the lack of predators. The ease of obtaining pork at an affordable price encourages fraudulent behavior by mixing or replacing beef with pork by meat millers.

Cytochrome $\mathrm{b}$ gene has a unique conserve area so that it can be known the history of a species and can be used as a genetic marker [5]. Cytochrome $b$ is encoded by mitochondrial DNA (Deoxyribose nucleic Acid), which is why Gen Cyt-b was used in studies related to the identification of raw meat and meat species that have undergone a warming process. Since species identification in food raw materials using the cytochrome $b$ gene has the advantage of being small in size, it then has a large copy, and there is no non-coding sequence [6].

The field of molecular genetics is currently often used for the identification of species in a food product. Methods of detection of meat species based on DNA such as PCR (Polymerase Chain Reaction) can detect DNA with very small samples to a certain level of sensitivity [7]. The amplification method with specific primers is the choice for analysis of pork content in beef grinding samples because of the high level of specificity and sensitivity. The amplification method with specific primers can amplify the target sequence in a meat matrix containing a small amount of sample [8]. That is why this research was conducted to detect pork contamination in beef grinding samples at several beef grinders in Bengkulu city markets using mitochondrial DNA cytochrome b genes. It is hoped that it can clearly identify the contamination of pork. So that there is no concern for the Muslim community in Bengkulu City when consuming processed beef.

\section{MATERIALS AND METHODS}

The first method is collection sampel, and then the sample is extracted to get DNA. isolate the genomic DNA by following the Dneasy mericon food protocol [9].
DNA amplification was performed using a PCR (Polymerase Chain Reaction) Simp Amp Thermal Cycler machine for 35 cycles: pre-denaturation for 4 minutes at $94{ }^{\circ} \mathrm{C}$, pre-denaturation at $95{ }^{\circ} \mathrm{C}$ for 4 minutes, denaturation at $94{ }^{\circ} \mathrm{C}$ for 1 minute, sticking primer (annealing) $63{ }^{\circ} \mathrm{C}$ for 1 minute; and lengthening (extension) at $72{ }^{\circ} \mathrm{C}$ for 1 minute. After that, the post-extension was carried out at $72{ }^{\circ} \mathrm{C}$ for 7 minutes. Furthermore, cooling (cooling).

PCR products were electrophoresed on $1 \%$ agarose gel. The gel well that was inserted with DNA and $1 \mathrm{~kb}$ markers were then run at a voltage of 50 volts for 40 minutes. Furthermore, soaked using Ethidium Bromide (EtBr) dye for 15 minutes. Furthermore, rinsed with distilled water for 1 minute. The electrophoresis result was then visualized under UV light using the Gel Document System Axygen.

\section{RESULT AND DISCUSSION}

The results of the electrophoresis still showed smears on the electrophoresis path. There are several causes for the appearance of scratches, namely the high voltage at electrophoresis so that the gel forms scratches. The formation of streaks is also influenced by the purity value of DNA, which means that DNA is contaminated with other substances [10]. The DNA bands between chickens and cows appear to be sticky and lighter, this is due to the adjacent amplicon lengths of chickens and cows, namely 227 bp and 274 bp.

The PCR visualization results showed that from 10 samples of ground beef, all samples showed the presence of bovine DNA bands based on Rcow primers and Reverse mix primers because the samples used were beef. Of the 10 samples, it is suspected that one sample was contaminated with pig DNA with a very thin DNA band. The thickness of the amplified DNA band is influenced by the number of isolated DNA, the more DNA is isolated, the thicker the DNA band. Conversely, the less DNA is isolated, the thinner the DNA bands are visualized on the agarose gel. Although the pig DNA content in the beef sample was very small, it could still be detected with cytochrome $b$ genetic markers. As in the study of Ni'mah [11] which detected pig DNA in samples of fresh beef and cooked beef using mitochondrial DNA markers cytochrome b. Ni'mah et al (2016) mix pork into beef with a percentage of $0 \%, 1 \%, 5 \%, 10 \%$ and $25 \%$ [11]. Pig DNA contamination in a product can be detected even though only $1 \%$ of its content is in the product. However, the S7 Sample cannot be said to be positive for contamination with pig DNA because the bands appearing are very thin and they could be smears or scratches. 


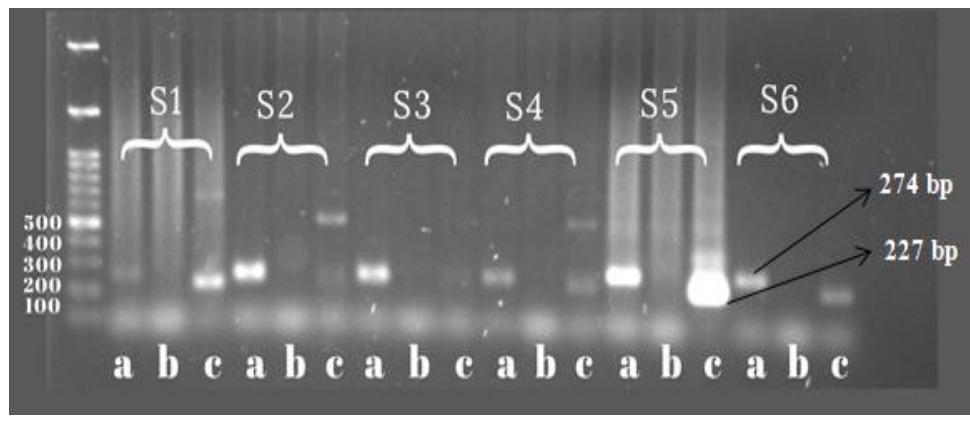

(a)

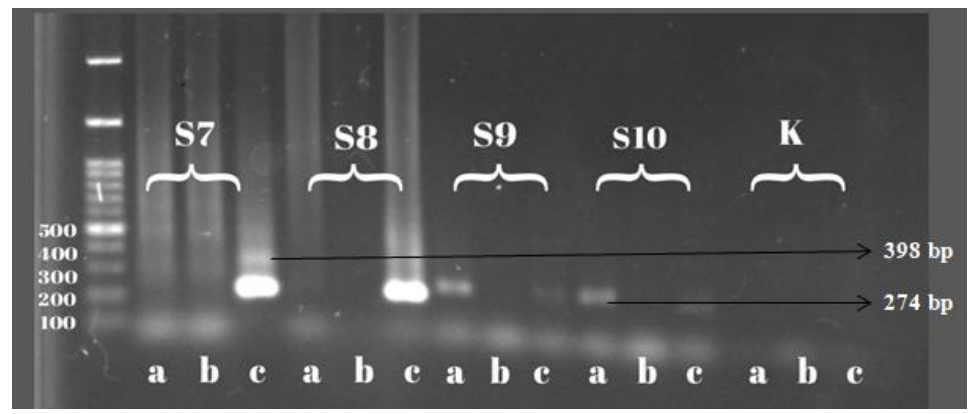

(b)

Figure 1. DNA site samples of ground meat in Bengkulu City. Information: (1) sample S1-S6, (2) sample S7-S8, (a) primary Rcow amplicon length 274 bp, (b) primary Rpork amplicon length 398 bp, (c) Reverse mix primer (chicken, beef, pig) amplicon length 227 bp, 274 bp, and 398 bp, (K) control

Table 1. Tabulation of contaminant research results on ground beef samples

\begin{tabular}{|c|c|c|c|c|c|c|c|}
\hline \multirow[t]{3}{*}{ No } & \multirow[t]{3}{*}{ Sample } & \multicolumn{5}{|c|}{ Primer } & \multirow[t]{3}{*}{ Information } \\
\hline & & \multirow[t]{2}{*}{ Cow } & \multirow[t]{2}{*}{ Pork } & \multicolumn{3}{|c|}{ Mix } & \\
\hline & & & & Chicken & Cow & Pork & \\
\hline 1 & $\mathrm{~S} 1$ & $\checkmark$ & - & $\checkmark$ & $\checkmark$ & - & Not valid \\
\hline 2 & $\mathrm{~S} 2$ & $\checkmark$ & - & - & $\checkmark$ & - & Not valid \\
\hline 3 & $\mathrm{~S} 3$ & $\checkmark$ & - & - & $\checkmark$ & - & Not valid \\
\hline 4 & $\mathrm{~S} 4$ & $\checkmark$ & - & $\checkmark$ & $\checkmark$ & - & Not valid \\
\hline 5 & S5 & $\checkmark$ & - & $\checkmark$ & $\checkmark$ & - & Not valid \\
\hline 6 & S6 & $\checkmark$ & - & $\checkmark$ & $\checkmark$ & - & Not valid \\
\hline 7 & S7 & $\checkmark$ & - & $\checkmark$ & $\checkmark$ & $\checkmark$ & Suspect \\
\hline 8 & S8 & $\checkmark$ & - & $\checkmark$ & $\checkmark$ & - & Not valid \\
\hline 9 & S9 & $\checkmark$ & - & - & $\checkmark$ & - & Not valid \\
\hline 10 & $\mathrm{~S} 10$ & $\checkmark$ & - & - & $\checkmark$ & - & Not valid \\
\hline
\end{tabular}

Information: $(\checkmark)$ there is DNA site, $(-)$ there is no DNA site

In addition to DNA from pigs and cows, the reverse mix primer used was also successful in detecting chicken DNA, namely samples S1, S4, S5, $\mathrm{S} 6, \mathrm{~S} 7$, and $\mathrm{S} 8$. The use of a reverse mix primer was used to prove the specificity of the cytochrome $b$ primer used. Amplification of the cytochrome $b$ gene in this study resulted in fragments of $389 \mathrm{bp}$ for pigs, $274 \mathrm{bp}$ for cows, and $227 \mathrm{bp}$ for chickens. The amplicon of the cytochrome $b$ gene in this study was consistent with Matsunaga et al. (1999) [12]. The 
success of the cytochrome $b$ gene amplification was indicated by the different length of the amplification fragment from 3 species, which means that there was specificity of the cytochrome $b$ gene sequence in each type of animal.

\section{CONCLUSION}

The 10 meat mills in several markets in Bengkulu City (Barukoto market, Sunday market, Serut River Fish Market, and Panorama Market) it is suspected that there is 1 meat mill where pig DNA is based on mixed primers, namely S7 sample. However, pig DNA was not found based on pig primers. In addition to pig DNA when using mixed primers, chicken DNA was also found in samples S1, S4, S5, S6, S7, and S8.

\section{REFERENCES}

[1] Undang-Undang Republik Indonesia Nomor 7 Tahun 1996 Tentang Pangan. [In Bahasa Indonesia]

[2] S. Almatsier, Prinsip Dasar Ilmu Gizi, Jakarta, Pustaka Utama, 2001. [In Bahasa Indonesia]

[3] E. Saputra, Strategi Pengembangan Usaha Penggilingan Daging di Kabupaten Seruyan Propinsi Kalimantan Tengah, Jurnal Galung Tropika, 6 (2) (2017) 103-113. [In Bahasa Indonesia]

[4] Undang-Undang Republik Indonesia Nomor 33 Tahun 2014 Tentang Jaminan Produk Halal. [In Bahasa Indonesia]

[5] B. Chance, R. Williams, The respiratory chain and oxidative phosphorylation, Advances in Enzymology and Related Areas of Molecular
Biology (17) (1956) 65-130. DOI: https://doi.org/10.1002/9780470122624.ch2

[6] A.A. Aida, Y.B. Che Man, C.M.V.L. Wong A.R. Raha, R. Son, Analysis of raw meats and fats of pigs using polymerase chain reaction for halal authentication, Journal. Meat Science (69) (2006) 47-52

[7] V. Fajardo, Real-Time PCR for detection and quantification of red deer (Cervus elaphus), fallow deer (Dama dama) and Roe deer (Capreolus capreolus) in meat mixtures, Meat Science 9(2) (2008) 289-298.

[8] K. Nakyinsige, Y.B.C. Man, A.Q. Sazili, Halal authenticity issues in meat and meat product, Meat Science 91(3) (2012) 207-214.

[9] Qiagen, DNeasy Mericon Food Handbook, Germany, Qiagen Sample and Assay Technology, 2014.

[10] S. Magdeldin, Gel Electrophoresis -Principles and Basics, 2012.

[11] A. Ni'mah, Y. Kartikasari, A.D. Pratama, L.R. Kartikasari, B.S. Hertanto, M. Cahyadi, Detection of pork contamination in fresh and cooked beef using genetic marker mitochondrial-dna cytochrome b by duplex pcr, Journal of the Indonesian Tropical Animal Agriculture 41(1) (2016) 7-12

[12] T. Matsunaga, K. Chikuni., R. Tanabe, S. Muroya, K. Shibata, J. Yamada, Y. Shinmura, A quick and simple method for the identification of meat species and meat products by PCR assay. Meat Science 5 (1999) 143-148 